811.163.41'374.81

811.163.41'367.6

https://doi.org/10.18485/msc.2018.47.1.ch6

Миливој Б. АЛАНОВИЋ*

Универзитет у Новом Саду

Филозофски факултет
Оригинални научни рад

Примљен: 03. 10. 2017.

Прихваћен: 27. 12. 2017.

\title{
РЕЧНИЧКИ ЧЛАНАК - ИЗВОР ПОДАТАКА О ФУНКЦИОНАЛНОЈ УПОТРЕБИ РЕЧИ
}

\begin{abstract}
Мада се указује на потребу разликовања лексичких, граматичких и функционалних речи, основни циљ овога истраживања јесте да истакне да лексикографска обрада може да помогне у одређивању значењских ресурса функционалних речи, као и прецизирању њихове граматичке позиције у реченици. Стога се управо на основу лексикографских дефиниција да закључити да функционалне речи нису синсемантичне лексеме, иако им је примарна улога да носе граматичке информације о конструкцији коју конституишу.

Кључне речи: функционална реч, структурна позиција, значење, речнички чланак.
\end{abstract}

\section{1. Увод}

Разврставање речи на лексичке и граматичке јединице постало је главним теоријским и методолошким начелом тек у теорији граматикализације (Крофт 2000: 156; Смирнова / Мортелманс 2010: 177), мада се и у, условно говорећи, традиционалним граматичким приступима класификација речи с обзиром на њихову службу и значење одавно одомаћила, у чему ни србистика није никакав изузетак, при чему се опет добијају две класе, овај пут самосталне и несамосталне или аутосемантичне и синсемантичне речи (Гортан-Премк 1997: 20, 30). Како се самосталност речи темељи на њиховој синтаксичкој дистрибуцији (Гортан-Премк 1997: 31), у том се погледу само именице и именичке заменице сматрају самосталним речима јер несметано и сасвим регуларно врше субјекатску функцију у реченици. С друге

\footnotetext{
*milivoj.alanovic@sbb.rs

** Овај рад је настао у оквиру пројекта бр. 178004 под називом Стандардни српски језик - синтаксичка, семантичка и прагматичка истраживања, који финансира Министарство просвете, науке и технолошког развоја Републике Србије.
} 
стране, само се именице, преко њих и именичке заменице, на основу своје семантичке аутономности сматрају независним речима (Стевановић 1979; Станојчић / Поповић 2014), док се све друге, захваљујући томе што се са овима доводе у непосредну везу, сматрају зависним лексичким јединицама. Као што видимо, значењски мотивисане класификације посебну улогу дају именицама у лексичком систему, али је ипак велико питање да ли се ово, у основи позитивистичко схватање које је још Белић заступао (Белић 1998[1941]: 34-35), може аутоматски применити и на логику граматичких структура, где у првом реду мислимо на реченицу, у којој се у многим правцима глаголу придаје највећа важност.

Напред поменута подела на лексичке и граматичке речи налази своје утемељење и у дијахроном аспекту развоја граматике, који подразумева да граматичке јединице настају од лексичких. Ипак, ова дихотомија, иако тесно везана за план значења речи, непосредно се тиче способности појединих речи да конституишу нове граматичке облике или парадигме (Дик 1997: 159; Смирнова/ Мортелманс 2010: 179-180), за које се усталио назив - граматичка реч. Последично, речи које не служе у ове граматичке сврхе називамо лексичким јединицама, које имају реално или референцијално значење. Тако, сасвим упрошћено речено, лексичке речи носе неко значење, док оне граматичке служе да се од лексичких речи формирају сложена или компонована значења. Примера ради, глагол јесам/бити у српском језику може имати обе поменуте употребе - граматичку, када служи за грађење, на пример, перфекта (je дошао), и лексичку, када има значење 'налазити се, боравити, одржати се' итд. (Ана је горе; Филм је сутра). Примери са глаголом јесам/бити сасвим уверљиво показују да се граматика пуни из лексике, па зато и не треба очекивати да је у свакој прилици могуће повући јасну границу између ова два плана језичкога функционисања. Међутим, питање које овом приликом желимо да размотримо јесте да ли поменута бинарна подела искључује постојање прелазне категорије речи, које се распоређују на периферији или у пресеку лексичког и граматичког система. Како је фазичност иманентна језику, није тешко замислити речи, нарочито глаголе али и именице, које у уобичајеним или примарним граматичким обрасцима испуњавају неку од улога граматичких речи, те за које зато и кажемо да су функционалне јединице.

\section{2. Функционалне речи}

У неким се лингвистичким традицијама, нпр. немачкој, под појмом функционалних речи подразумевају предлози, везници, чланови, партикуле, дакле, речи које немају способност да непосредно врше функцију реченичног члана (Хелбиг/ Буша 1996: 142-188; Ајзенберг 2013: 13). Иако се у овом приступу, примећујемо, прави једнакост између функционалних и граматичких речи, овај термин сматрамо врло погодним да се примени на категорију прелазних јединица између лексике и граматике. Како се, већ смо рекли, систем граматичких речи попуњава из лексике, тако би се функционалним јединица- 
ма могле сматрати речи ослабљенога лексичкога значења, које, премда указују на специфичне значењске или пропозиционе односе у реченици, немају способност да граде нове граматичке категорије.

2.1. Иако се од глагола очекује да их сретнемо у функционалној или граматичкој употреби, о чему ће у наставку рада и бити највише речи, и међу именицама се могу наћи оне које указују на специфичне значењске односе у реченици, тј. на устројство њене пропозиционе структуре, које тако врше неку специфичну операторску функцију.

За ову прилику искористићемо само два типа именичких оператора, и то оне дијатетичке и сирконстантне.

У примерима типа

(1) Formalna ispravnost izveštaja stranaka je bila predmet razmatranja (П).

(2) Kunderina slava oduvek je bila tema javnih polemika (П).

(3) Prošle godine Jugoslavija je bila objekat agresije NATO-a... (П).

(4) Antički teatar je mesto susreta starih ljubavnika (П).

(5) Prvih pedesetak godina 19. veka je vreme traženja ,bibliografskog izraza" (AB).

лако се да уочити исти тип граматичке структуре коју конституише глагол је-

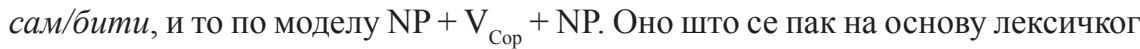
састава примера (1)-(5) може утврдити јесте да ови имају потпуно различите пропозиционе садржаје, и то:

(1') Разматрали су формалну исправност извештаја странака.

(2') Полемисали су о Кундериној слави.

(3') НАТО је извршио агресију на Југославију.

(4') Стари љубавници се сусрећу у античком театру.

(5') Библиографски израз су тражили у првих педесетак година 19. века.

Иако структуру пропозиције одређује њен предикат, чији су експоненти у овом случају именице разматрање, полемика, агресија, сусрет и тражене, структуру реченица (1)-(5) одређује, разуме се, финитни глагол јесам/ бити, који, међутим, није експонент пропозиционог предиката. Померање пропозиционог предиката на неглаголску позицију најбољи је показатељ нелексичке употребе финитума, што, међутим, не решава проблем распоређивања осталих пропозиционих чланова у реченици. Одговор на ово лежи у функционалном потенцијалу именица предмет, објекат, тема, место и време, које омогућују специфичан граматички распоред различитих пропозиционих чланова. Како регулишу одговарајућу перспективу, ове именице називамо - тематизаторима. Међутим, с обзиром на то да се у примерима (1), (2) и (3) тематизацији подвргавају пропозициони објекти, док су у (4) и (5) тематизовани пропозициони адвербијали, или сирконстанти, стога именице предмет, објекат и тема дефинишемо као дијатетичке а именице место и време као сирконстантне операторе.

Кључно питање које се овде намеће јесте у чему се огледа специфична операторска функција наведених именица, када знамо да се оне појављују у истом граматичком обрасцу, као и да конституишу исти тип именичке син- 
тагме, и то NP [NP + NP], нпр. предмет анализе, објекат агресије, тема расправе, место сусрета, време заљубљивања итд. На варијантност или пак слабљење основног значења пажњу скреће и лексикографска обрада у РСАНУ и PMC. Тако се, на пример, за именицу предмет у РМС (PMC 4: 907) наводи да може означити „оно што служи као извор каквих осећања, емоција”, попут предмет подсмеха/љубави, а за објекат у РСАНУ (РСАНУ 16: 277) да означава „оно што је обухваћено нечијом делатношћу”, као објекат студије/занимањ $а$, чиме се недвосмислено указује на каузативни карактер означенога појма, односно на његово пасивно учешће у каквој радњи. С друге стране, једно од значења именице време у РСАНУ (РСАНУ 3: 43) јесте и „тренутак, доба кад нешто бива", као у време рођењ $а$, док за именицу место стоји да се њоме може означити „служба”, „функција” или „улога” неког појма (РСАНУ 12: 429), типа место рођењ $a$. Коначно, дефиниција именице тема, иако без одговарајућих примера, довољно је општа - „предмет, основа, главна мисао (расправе, говора)" (РМС 6: 176).

Ако се сада вратимо нашим примерима, примећујемо да реченице (1), (2) и (3) представљају посебан вид пасива, и то оног лексичког (Бондарко 2002: 604; Алановић 2009: 127), јер се одговарајући дијатетички образац не добија на основу граматике реченичне структуре већ на основу њеног лексичког састава. Дакле, у примерима (1)-(3) управо дијатетички оператори дају податак да је субјекатски појам објекат разматрања, полемике, односно агресије. Међутим, њима се и облик учешћа објекатског појма у денотираној радњи конкретизује, што значи да се именицама предмет и објекат указује на његову пацијативну а именицом тема на тематску улогу, што значи да се овде не ради о десемантизованим речима, премда своје непосредне корелате у пропозиционој структури реченице не налазе, што оверава њихову нелексичку употребу.

На сличан начин се могу интерпретирати и примери (4) и (5). Наиме, именицама место и време одређује се улога субјекатског појма у денотираној ситуацији или радњи, односно реферише о његовој пропозиционој функцији, будући да се датом копулативном конструкцијом не износи никаква квалификација субјекта, тим пре што се реченице типа Антички театар је место и Првих педесетак година 19. века је време тек условно могу прихватити као оверени језички искази.

Овај кратак осврт на значење и прагматичку функцију копулативних конструкција (1)-(5) потврђује неке полазишне премисе, а то су:

(a) функционалне речи се појављују у за њих уобичајеним граматичким обрасцима;

(б) функционалне речи чувају део свог лексичког значења;

(в) иако није реч о синсемантичним јединицима, функционалне речи углавном немају директне пандане у пропозиционој структури реченице.

Функционалне именице предмет, објекат, тема, место и време, премда указују на граматичке односе у пропозиционој структури реченице, не 
испуњавају, дакле, кључан услов да их третирамо граматичким јединицама. Без обзира на то што нису употребљене у сврху квалификације, категоризације или идентификације субјекта, ове именице ипак показују ограничења у погледу свог колокационог потенцијала, што дугују очуваности дела свог лексичког значења. Нпр.:

(5) Пасив је предмет/тема истраживања.

(6) Министар је био предмет/објекат напада.

(7) Вече је време изласка ноћобдија.

(8) Корзо је некада био место изласка младих.

Тако, док тип реченичне конструкције омогућује тематизацију и класификацију једног елемента ситуације, дотле именички тематизатор одређује улогу датог елемента у ситуацији.

2.2. Функционалну употребу имају и глаголи, премда се у домаћој лингвистичкој пракси одомаћио термин семикопулативни глагол (Радовановић 1990: 54, 59).

Иако је још увек преовлађујуће начело да се ове конструкције третирају као јединствене синтаксичке јединице, овом приликом желимо да се осврнемо на неколико кључних чињеница, важних за структуру и значењску организацију глаголских перифраза, односно декомпонованих и/или перифрастичних предикатских израза (Тополињска 1982; Радовановић 1990; Мразовић 2009). У прилог ставу да су глаголске перифразе сложене синтаксичке конструкције, чији саставни елементи показују значајан степен граматичке аутономности (Еромс 2000: 164), свакако иде могућност да се подвргну неком од следећих лексичко-граматичких тестова, а то су:

(a) супституција једног или оба елемента предикатске конструкције;

(б) пасивизација предикатске конструкције;

(в) анафоричка замена именичког конституента конструкције;

(г) увођење факултативних додатака/одредаба уз именички регенс.

Уколико упоредимо предикатске изразе типа дати/пружити/изразити подршку, примећујемо да се у основи сваког од њих налази исти пропозициони предикат, и то 'подржати', док различити функционални глаголи у њима регулишу, у начелу, акционални карактер радње. Осим тога, глаголи дати и пружити у колокабилној су вези са именицама типа прилика, шанса и сл., за разлику од глагола изразити који колоцира са именицама попут сnремност, жаљење итд. Ових неколико варијантних облика истог граматичког типа глаголске перифразе показује да њено значење непосредно зависи од лексичке селекције, тј. од комбинабилности лексичких јединица, при чему у колокабилни однос могу ступити само лексички компатибилне јединице, што значи да оба елемента конструкције имају (неко) значење. И даље, различите комбинаторичке варијанте са глаголом типа дати, са једне стране, и са именицом типа подршка, са друге, показују да нема основа говорити о фраземима, те да је више него оправдано анализирати и граматичку организацију глаголских перифраза. 
Управо на могућност, или пак потребу, испитивања граматичке организације глаголских перифраза пажњу скрећу и примери типа На ово му је више пута скренута пажња, Напад је извриен из заседе, Издата је наредба о испловљаваюу брода итд., у којима се перифразе скренути пажюу, извриити напад и издати наредбу појављују у пасивном облику - пажња је скренута, напад је извршен и наредба је издата. Иако делује као светогрђе у саставу перифраза идентификовати субјекат и објекат глагола, пасивна трансформација доказује да њих конституише глагол са једном својом депенденцијом, или функционалном пројекцијом, која се у случају лексичке употребе глагола назива субјекат, објекат или пак адвербијал, нпр. Хвата ме трема; Имам жељу да те посетим; Умешао се у разговор и сл. Иако неки лингвисти указују да овакав приступ не задовољава потребе семантичке анализе (Пафел 2011: 45), неспорно је да перифразе представљају граматичке конструкције у чијој се основи виде неки мотивациони механизми њиховога настанка, а они се углавном тичу персонификације, супстанцијализације и оријентације као основних метафоричких сценарија у језику и мишљењу (Вилдген 2008: 79-82).

Ипак, далеко већи проблем за синтаксичку анализу представљају примери глаголских перифраза у којима се на семантичко језгро предикативности указује заменичком анафором. Нпр.:

(9) Наредба која је издата још није извршена.

У реченици (9) могу се идентификовати барем две пропозиције, које конституише исти предикат - 'наредити'. Осврт на граматичку организацију реченице пак показује да су сви елементи у релативној реченици која је издата, у ствари, део предиката, који своје лексичко 'пуњење' задовољава тек анафоричком везом између релативизатора која и антецедента наредба. Ова појава, на свој начин, истиче релативну лабавост значењских веза унутар перифразе, при чему ову лабавост треба пре тумачити као изборност.

Када је већ реч о изборности елемената унутар перифразе, она се понајпре тиче именичких додатака/одредаба. Нпр.:

(10) Дао им је безрезервну подршку.

(11) Примио је снажан ударац у леђа.

(12) Дао му је могућност избора.

Ширење предикатске конструкције именичким одредбама/додацима или допунама јесте у домену именичке валентности, факултативне или облигаторне, што у највећем броју случајева нема утицаја на значење предикатског израза. Наиме, именички атрибути додатног типа, као у (10) и (11), углавном означавају ситуационе околности под којима се врши радња, док они допунског типа редовно стоје у корелацији са пропозиционим предикатом. Тако, у примеру (12) именица могућност је модални оператор као што је то и глагол моћи, због чега је именица избор, иначе на допунској позицији, тада експонент пропозиционог предиката. С друге стране, придеви безрезерван и снажан алтернирају са одговарајућим адвербијалима, нпр. Безрезервно их подржава и Снажно је ударен у леђа. 
Све досад речено, сматрамо, недвосмислено указује да глаголске перифразе треба посматрати као сложене синтаксичке јединице, као и да се границе предиката, као функционално-семантичке јединице, не морају нужно поклапати са границама реченичних чланова. Зато, подсећања ради, у депенденцијалној граматици реченични центар не представља предикат већ финитни глагол, односно глаголски комплекс састављен од финитног и централног глагола, где је централни глагол носилац валентности (Енгел 2009: 119-120).

\section{3. Значење функционалних глагола}

Раније смо рекли да и неки типични граматички глаголи, као што је то јесам/бити, имају лексичку употребу, тј. лексичко значење. Аналогно овоме, и неки пунозначни глаголи имају копулативну употребу, што не значи и потпун губитак лексичког значења. Нпр.:

(13) Остали смо пријатељи.

(14) Постали смо пријатељи.

(15) Ово представља велики проблем за мене.

Тако, у примеру (13) какво својство субјекта важи и у тренутку говорења као и пре њега, у (14) се пак изражава промена својства, тј. наступање новога својства, док се у (15) нарочито истиче, издваја какво својство субјекта. Дакле, поменути семикопулативни глаголи су значењски далеко сложенији од јесам/бити, што значи да се слабљење њиховога значења тиче само неспособности да се непосредно идентификује процес или какво својство.

Управо и лексикографска обрада појединих глагола сугерише на феномен слабљења а не и потпуног губитка значења, нпр.: бавити се - „занимати се, радити” (РСАНУ 1: 226), нпр. бавити се увозом беле технике; бацити ce - „Прионути енергично на неки посао” (РСАНУ 1: 346), нпр. бацитти се на писање; беснети - фиг. „испољавати се у свој својој силини” (РСАНУ 1: 495), нпр. рат бесни; борити се - „улагати или преживљавати напоре при решавању, достизању, савлађивању нечега и при одолевању нечему” (РСАНУ 2: 271), нпр. борити се са дуговима; букнути - „бити нагло обузет каквим осећањем”, „нагло настати”, „нагло се појавити” (РСАНУ 2: 271), нпр. букнуо је рат; вршити - „чинити, извршити неку радњу” (РСАНУ 3: 109), нпр. вршити претицање; вући - „отезати, развлачити” (РСАНУ 3: 129), нпр. вући прехладу; гајити - фиг. „одржавати, чувати, развијати, унапређивати” (РСАНУ 3: 164), нпр. гајити симпатије; горети - фиг. „бити обузет неком великом страшћу, неким јаким осећањем" (РСАНУ 3: 482), нпр. горети од љубави; губити - „престати имати” (РСАНУ 3: 728), нпр. губити разум/наду; дати - „условити”, „бити узрок нечега”, „помоћи да се постигне нешто” (РСАНУ 4: 66-67), нпр. дати дозволу; дићи - „предузети, покренути, започети” (РСАНУ 4: 352), нпр. дићи побуну; добити - „доживети неку промену, развити, стећи неку особину”, „бити захваћен нечим” (РСАНУ 4: 384), нпр. добити ударащ; довести - „бити узрок, услов неког збивања, догађаја”, „проузроко- 
вати неку промену” (РСАНУ 4: 412-413), нпр. довести у склад/срибу/до суза; донети - „проузроковати, причинити, створити” (РСАНУ 4: 537), нпр. донеmи срећу; доћи - „постати”, „бити доведен у неке околности, у неко духовно или физичко стање”, , стићи до извесног ступња, постићи нешто” (РСАНУ 4: 617-618), нпр. доћи на мисао/у опасност/за председника; држати - „прожимати, испуњавати, обузимати не попуштајући" (РСАНУ 4: 706), нпр. држси га сета; дрмати - „држати у потпуној контроли, власти” (РСАНУ 4: 717), нпр. дрма га пубертет; дужити - „настављати, продужавати” (РСАНУ 4: 9), нпр. дужити разговор.

Обрада датих глагола у РСАНУ открива оквире њихове функционалне употребе, упућујући да је реч о регулаторима фазе радње или њенога трајања, дијатезе, резултативности, интензитета итд.

Међутим, понекад се са неједнаком лакоћом да утврдити остатак лексичког значења функционалног глагола, мада су значењске варијације очите код перифраза са истим пропозиционим предикатом, типа 'дискутовати', попут водити / кренути / мамити / претворити се / убацити / укључити се / умешати се / упасти / уплитати се / упуштати се / ући у дискусију, нпр.:

Nije se upuštao u diskusiju da li je ono moglo da bude izbegnuto da je njegova stranka od 1990. vodila drugačiju politiku... (П); Ovom prilikom su se uključili u diskusiju i gledaoci... (П); Ja ne bih želeo da se unesem u diskusiju između UNMIK-a i odgovarajućih vlasti... (НИН); Ulaze u diskusiju jer shvataju da je to pošten predlog (П); S jedne strane, one vode u diskusiju konstitutivnih odredaba novog uređenja što izlazi iz naše kompetencije... (КП); ...pošto se ovde upliću u diskusiju ličnosti koje s ovim nemaju veze... (OП); ...što privlači veliku pažnju i prosto mami ljude u diskusiju (П); VSO je krenuo u diskusiju o „,aferi Perišić”... (НИН); ...u diskusiju o ciframa ovde se ne možemo upuštati... (П); ...kako da se uđe u diskusiju o evropskim integracijama i situaciji na Kosovu bez mišljenja vlade (П); Uprkos tome i tako značajne teme, sastanak se, međutim, pretvorio u diskusiju o najnovijim političkim promenama u Jugoslaviji... (П); Kada i ove vrednosti uključimo u diskusiju o srpskoj evropeizaciji, onda moramo postaviti pitanje... (П); Kasnije je Leni Tristano upao u diskusiju sa mnom i Berdom (ЧM); U diskusiju se, neočekivano, umešao i predsednik republike Hajnc Fišer (П); Glavna prednost korišćenja ove tehnologije jeste mogućnost da se u diskusiju ubace podaci ili vizuelne slike (BM);

или пак 'спорити се', као довести / мешати се / прерасти / ступити / увести / уклизавати / укључити се / уметати / умешати се / уплести се / упустити се / ући у спор, нпр.:

Sud kome je podneta glavna tužba određuje rokove za saopštavanje i za stupanje u spor (3); ...ne koristi državama koje su upletene u spor... (П); Nema stranaka raspoloženih da se umešaju u spor DS- a i DSS-a... (П); ...naglasio da se policija neće mešati u spor dve suprotstavljene strane u Novom Pazaru i Sjenici (П); Sanader je pozdravio uključivanje Evropske komisije u spor... (PTC); ...sudska procedura zahteva da se pita i tužena strana, ako se ona već upustila u spor... (PTC); Posredničku sposobnost implicite mu priznaje čak i Platon kada ga umeće (kao «pomiritelja») u spor između Protagore i Sokrata... (ВЦ); ...kad bi Bžežinski pristao da uđe u spor (ПКД); ...Afera «Mreža», koja je počela kao obračun sa duvanskom mafijom, prerasla je u spor... (П); Na uzajamnost u izvršenju se, dakle, poziva tuženi i on je, ako to hoće, uvodi u spor (МД); Odbor za hitna pitanja FSJ neće ulaziti u spor sa dosadašnjim prvim stručnjakom... (П); Ali to je novog predsednika dovelo u spor sa papom Benediktom Šesnaestim (П); Ono što me uporedo s tim brine je utisak da Beograd uklizava u spor sa Ujedinjenim nacijama (П).

Иако наведене перифразе обједињује исти пропозициони предикат, 'дискутовати' или 'спорити се', свакако не вара први утисак да није реч о 
синонимским изразима, барем не оним правим или потпуним, што уверава да су функционални глаголи, заправо, модификатори или пак конкретизатори значења целога израза. Тако, на пример, уз фазну модификацију радње, појединим се глаголима означавају различите модалне категорије, као што су циљноусмерено или планирано учешће у радњи (кренути, укључити се, $y \hbar u)$, неспремност, несигурност или невољност учешћа у радњи (упустити ce), нецелисходно и ометајуће дејство на радњу (уплитати се, умешати се) и сл., при чему се као пратеће компоненте појављују и значења као накнадно или непожељно учешће у радњи итд. (укључити се, убацити се, уплитати се и сл.). С друге стране, међу операторе каузативне дијатезе, уз укљуучити, умешати, уплитати и сл., који чувају напред наведена модална значења, убрајамо још и водити, мамити итд., од којих први додатно регулише резултативни а други мотивациони карактер каузације, што значи да радња настаје као ефекат каузације, односно да њена реализација зависи од воље и спремности објекта каузације да је реализује. Коначно, глаголи типа претворити се представљају резултативно-трансформационе операторе, с обзиром на то да реферишу о промени или смени процеса.

\section{4. Закључак}

Концепт функционалне употребе глагола, али и не само њих, темељи се на способности речи да регулишу одређене дијатетичке, аспектуалне, акционалне и модалне категорије. У овоме раду смо посебно желели да истакнемо да разматрању значењског потенцијала функционалних речи повод или утемељење дају и лексикографски описи, за разлику од оних граматичких који овом феномену не придају већу пажњу, што све заједно узев доказује да лексика и граматика чине континуум, а не два одвојена модула.

Функционални значењски опсег глагола може се представити као семантички 'остатак', настао након екстракције процесуалне семантичке компоненте из његовог примарног значења. Иако није увек лако утврдити садржај тога остатка, неспособност глагола да непосредно означи процес не значи и да нема некакво значење, што управо значењске варијације у перифразама са истим пропозиционим предикатом доказују.

\section{ИЗВОРИ}

Грађа је преузета и са сајта www.korpus.matf.bg.ac.rs, а тачан списак извора je: AB - А. Вранеш, Српска библиографија у области књижевности, језика и библиотекарства у листовима, новинама и часописима од Орфелина до 1941. године: теорија и историја; ВМ - Вилијам Мастерсон, Организаиија универзитетских библиотека: искуства Велике Британије; ВЦ - Владимир Н. Цветковић, Полис и филозофија: античка фи- 
лозофија и њен историјско-политички хоризонт, Кн. 1, Од Талеса до Платона; 3 - Закон о потврђиваюу протокола од 3. јуна 1999. године о изменама конвениије о међународним железничким превозима од 9. маја 1980; КП - Комнене Пијавец и др., Записници са седница Министарског савета Краљевине Југославије: 1941-1945; НИН; МД - Младен Драшкић и др., Уговорно право међународне трговине; ОП - Олга Поповић Обрадовић, Парламентаризам у Србији: од 1903. до 1914; П - Политика; ПКД - Политикин културни додатак; РТС; ЧМ - Чарлс Мингус, Беднији од шугавог пса.

PMC: Речник српскохрватскога књижевног језика, Нови Сад: Матица српска (I-VI) - Загреб: Матица хрватска (I-III), 1967-1976.

РСАНУ: Речник српскохрватског књижевног и народног језика, Београд: Институт за српски језик Српске академије наука и уметности (1-19), $1959-$.

\section{ЛИТЕРАТУРА}

Ајзенберг 2013: Peter Eisenberg, Grundriss der deutschen Grammatik. Band 2: Der Satz, Stuttgart: Metzler.

Алановић 2009: Миливој Алановић, Лексичко-синтаксичка средства пасивизације, Научни састанак слависта у Вукове дане, 38/1: 123-133.

Белић 1998[1941]: Александар Белић, Општа лингвистика (прир. Милка Ивић), Београд: Завод за уџбенике и наставна средства.

Бондарко 2002: Александр Бондарко, Теория значения в системе функииональной грамматики: на материале русского языка, Москва: Языки славянской культуры.

Вилдген 2008: Wolfgang Wildgen, Kognitive Grammatik. Klassische Paradigmen und neue Perspektiven, Berlin - New York: Walter de Gruyter.

Гортан-Премк 1997: Даринка Гортан-Премк, Полисемија и организаиија лексичког система у српскоме језику, Београд: Институт за српски језик САНУ.

Дик 1997: Simon C. Dik, The Theory of Functional Grammar. Part 1: The Structure of the clause, Berlin - New York: Mouton de Gruyter.

Енгел 2009: Ulrich Engel, Syntax der deutschen Gegenwartssprache, Berlin: ESV.

Eромс 2000: Hans-Werner Eroms, Syntax der deutschen Sprache, Berlin - New York: Walter de Gruyter.

Крофт 2000: Wiliam Croft, Explaining Language change: An Evolutionary Approach, Harlow: Longman.

Мразовић 2009: Pavica Mrazović, Gramatika srpskog jezika za strance, Novi Sad - Sremski Karlovci: Izdavačka knjižarnica Zorana Stojanovića.

Пафел 2011: Jürgen Pafel, Einführung in die Syntax, Stuttgart - Weimar: J. B. Metzler.

Радовановић 1990: Milorad Radovanović, Spisi iz sintakse i semantike, Novi Sad - Sremski Karlovci: Dobra vest - Izdavačka knjižarnica Zorana Stojanovića. 
Смирнова/ Мортелманс 2010: Elena Smirnova, Tanja Mortelmans, Funktionale Grammatik. Konzepte und Theorien, Berlin - New York: Walter de Gruyter.

Станојчић/Поповић 2014: Живојин Станојчић, Љубомир Поповић, Граматика српског језика за гимназије и средње иколе, Београд: Завод за уџбенике.

Стевановић 1979: Михаило Стевановић, Савремени српскохрватски језик II, Београд: Научна књига.

Тополињска 1982: Зузана Тополињска, Перифрастични предикатски изрази на међусловенским релацијама, Јужнословенски филолог, XXXVIII: 35-49.

Хелбиг/ Буша 1996: Gerhard Helbig, Joachim Buscha, Leitfaden der deutschen Grammatik, Leipzig: Langenscheidt.

Milivoj B. Alanović

WÖRTERBUCH: DATENQUELLE ÜBER FUNKTIONALEN GEBRAUCH VON WÖRTERN

Zusammenfassung

Der Ausgangspunkt dieser Arbeit ist, dass Wörter dreifachen Gebrauch haben können - lexikalischen, grammatischen und funktionalen, wobei wir bewiesen haben, dass funktionale Verben keine bedeutungslosen Wörter sind. Funktionale Verben bilden Prädikatskonstruktionen, die als syntaktische Einheiten betrachtet werden sollen. Außerdem, um den semantischen Inhalt dieser Verben zu erfassen, kann von großer Hilfe das Wörterbuch sein, in dem ein solcher Gebrauch schon beschrieben worden ist. Schlüsselwörter: Funktionswörter, strukturelle Position, Bedeutung, Wörterbuch. 